\title{
Observation on the Host Reaction to the Cultivated M. lepraemurium in the Spread Subcutaneous Tissue Preparations of Mice
}

\author{
MASANORI MATSUOKA and YOICHIRO KAWAGUCHI \\ (National Institute for Leprosy Research)
}

(Received for publication: November 26, 1981)

\begin{abstract}
Since the first successful cultivation of $M$. lepraemurium was reported by Ogawa $\left({ }^{1}\right)$, it was examined and confirmed by others $\left({ }^{2,3,4}\right)$. Colonies of $M$. lepraemurium on Ogawa's $1 \%$ egg yolk medium are originally rough, but they become smooth, in general, after 10 to 15 cultural passages $\left({ }^{5}\right)$. Surface of the colonies changes from heaped-up and wrinkled to flat and glistening during serial subcultures. Remarkable ultrastractural differences on the surface substances of the bacilli were recognized between these two colonies by scanning electron microscopic studies $\left({ }^{6,7}\right)$.
\end{abstract}

As staded in our previous reports $\left({ }^{8,9,10}\right)$ on the pathogenicity for mice of cultivated $M$. lepraemurium, bacilli from rough colonies of Hawaiian-Ogawa strain (HO-R) were more virulent than those of original Hawaiian strain maintained only by $\mathrm{C} 3 \mathrm{H}$ strain mouse passages (H-M). HO-R bacilli developed malignant type leproma at the inoculation site in male DDD strain mice, in which the subcutaneous lesion with H-M bacilli usually developed benign type leproma. The bacilli from smooth colonies (HO-S) were generally much less virulent for mice than HO-R and H-M bacilli $\left({ }^{11}{ }^{12}\right)$. HO-S bacilli did not develop any palpable leproma at the inoculation site even in the highly susceptible $\mathrm{C} 3 \mathrm{H}$ mice in long term observation.

Since the spread subucutaneous tissue preparation technique has been found to be reliable and useful for observing the host parasite relation at the early stages of subcutaneous infection with $M$. lepraemurium $\left({ }^{13}\right)$, this technique was applied to investigate the host reaction and the growth pattern of bacilli at early stages of the infection with HO-R and HO$\mathrm{S}$, up to 10 weeks.

\section{Materials and Methods}

Experiment I. Observation on the growth pattern and the host reaction after subcutaneous infection with HO-R bacilli.

Animals. Five to six week old male mice of $\mathrm{C} 3 \mathrm{H}, \mathrm{BALB} / \mathrm{c}, \mathrm{C} 57 \mathrm{BL} / 6$ and $\mathrm{DDD}$ strains were used. These mice were bred and raised in our laboratory.

Bacterial material and inoculation. Rough form $M$. lepraemurium was obtained from 8 th subculture of Hawaiian-Ogawa strain. This strain was isolated from subcutaneous leproma of $\mathrm{C} 3 \mathrm{H}$ mouse previously infected with $M$. lepraemurium, strain Hawaiian and maintained on the Ogawa's $1 \%$ egg yolk medium with serial passages et every 6 week cultivation $(1,2,3,4)$. 
The bacterial suspension approximately containing $2 \times 10^{8}$ organisms in $1 \mathrm{ml}$ of saline was prepared by the grinding method. Each mouse was inoculated subcutaneously in the back with $0.25 \mathrm{ml}$ of the suspension.

Preparation and observation. Two or three mice were killed at weekly intervals untill 10 weeks after the infection. Four to five pieces of spread subcutaneous tissue preparation (STP) were made from the inoculation site in each mouse by the method described in detail previously $\left({ }^{13}\right)$. The skin of mouse was cleaned and disinfected with alchohol. An incision was made at the side of abdomen and the skin was inverted. Subcutaneous tissue was grasped with scissors and placed on the glass slide. The tissue was spread out with the tip of scissors and plastered to the slide in an area of about 2 to $4 \mathrm{~cm}^{2}$. The specimens were left at room temperature for drying, fixed by passing through a flame and stained by Ziehl-Neelsen method. All specimens were processed for examination by light microscopy (Fig. 1).

Experiment II. Observation on the growth pattern and the host reaction after subcutaneous infection with HO-S bacilli.

Fxp. II -1 . Male mice of $\mathrm{C} 3 \mathrm{H}$ and $\mathrm{C} 57 \mathrm{BL} / 6$ strains were inoculated with bacterial suspension of HO-S bacilli prepared as the same manner in Experiment I. The bacterial suspension was prepared from the 36 th subculture, 6-week-old, of Hawaiian-Ogawa strain which had changed from rough to smooth at the 21 th subculture. Observation was made by the same manner as in Experiment I.

Exp. II-2. Observations were done also on male $\mathrm{C} 3 \mathrm{H}, \mathrm{BALB} / \mathrm{c}$ and $\mathrm{DDD}$ mice by the same manner in Experiments I and II-1, except the 42 th subculture of the same strain was used for this experiment.

\section{Results}

Exp. I. The growth pattern and the host reaction in the host infected with HO-R bacilli.

At 2 days, polymorphonuclears were seen dominantly at the inoculation site as a remain of acute inflammatory reaction. Many macrophages, mononuclears and a few lymphocytes were also seen. Most of the bacilli were ingested by macrophages. There were 10 to 20 bacilli in each macrophage. The form of bacilli was short $(2-2.2 \mu)$ and thick as similar to that of initials. No remarkable differences on cellular reaction were recognized at this time among mouse strains.

At one week, the infiltration of polymorphonuclears disappeared in $\mathrm{C} 3 \mathrm{H}$ mice, but in the other three strains some polymorphonuclears were still left at the inoculation site.

At 3 weeks, no macroscopic lesions were seen in $\mathrm{C} 3 \mathrm{H}$ mice, whereas a benign type nodule developed at the inoculation site in $\mathrm{C} 57 \mathrm{BL} / 6, \mathrm{DDD}$ and $\mathrm{BALB} / \mathrm{c}$ mice. No good specimens could be obtained from the central part of inoculation site in these three strains of mice, (C57BL/6, DDD and $\mathrm{BALB} / \mathrm{c}$ ), because it is so difficult to strip off subcutaneous tissue and to spread the tissue as a monolayer on the glass slide. In these three strains of mice, many 
polymorphonuclears and lymphocytes were obsereved and the bacilli seen in macrophages at a part of preparation were segmented or beaded. In $\mathrm{C} 3 \mathrm{H}$ mice, morphological changes and increase in number of the bacilli were not recognized yet and cellular reactions such as in the other three strains were not seen.

At 5 weeks, cellular reaction and multiplication of the bacilli showed remarkable differences between $\mathrm{C} 3 \mathrm{H}$ and other three strains of mice. In $\mathrm{C} 3 \mathrm{H}$ mice, cellular infiltration was mainly consisted of macrophages and mononuclears and most of macrophages were heavily loaded with uniformly stained, thick and a little elongated bacilli (Fig. 2, 3). These macophages, called murine leprosy cell, were diffusely scattered or occasionally accumulated in whole fields of specimens. Bacillary multiplication was clearly revealed from these features. In contrast, severe infiltration with lymphocytes and polymorphonuclears was seen in $\mathrm{C} 57 \mathrm{BL} / 6, \mathrm{BALB} / \mathrm{c}$ and DDD mice. The cellular reaction was more severe in DDD mice and no murine leprosy cells were seen in the preparations. In C57BL/6 mice (Fig. 4, 5) and BALB/c mice, a few numbers of murine leprosy cells which contained about 10 bacilli of non-solid form, were surrounded by many lymphocytes and polymorphonuclears.

At 8 weeks, in $\mathrm{C} 3 \mathrm{H}$ mice, further increase of murine leprosy cells was observed in the whole fields. Most of these cells were loaded with 50 bacilli or more which were short and uniformly stained. In $\mathrm{BALB} / \mathrm{c}$ and $\mathrm{C} 57 \mathrm{BL} / 6$ mice, the number of murine leprosy cells were much less than at the earlier stages of infection. In these mice the murine leprosy cells were surrounded more heavily by lymphocytes and polymorphonuclears than those observed in 5 weeks and these murine leprosy cells contained a few bacilli. Some bacilli were seen extracellularly, probably resulting from the bursting of bacilli-loaded macrophages. Most of the extracellular bacilli showed a segmented or beaded form. These features indicated that further local spread of the infection was arrested in these three strains. In DDD mice different two features were obsereved, one DDD mouse showed the same features as BALB/c and C57BL/6 mice but another one showed the features of cellular reaction and bacillary multiplication which were quite different from the former one. In the former mouse, a few extracellular bacilli were found in severe infiltration of lymphocytes and polymorphonuclears. In the latter mouse there were many murine leprosy cells which were heavily loaded with short bacilli, without any cellular reaction of lymphocytes and polymorphonuclears in some parts of the specimen, but in other parts of the same specimen, the same feartures as observed in $\mathrm{C} 57 \mathrm{BL} / 6$ were seen.

At 10 weeks, a small malignant leproma was seen macroscopically at the site of infection in $\mathrm{C} 3 \mathrm{H}$ mice and the cellular infiltration was mainly consisted of murine leprosy cells. Notable changes in cellular reaction at this stages were not observed in $\mathrm{BALB} / \mathrm{c}$ and C57BL/6 mice.

In DDD mice many small masses of murine leprosy cells were found as islands in the specimen (Fig. 6). In this area there were some lymphocytes and polymorphonuclears, but they did not accumulate around the masses of murine leprosy cells. Significant increase of bacillary number was recognized at this stage. 
Exp. II. The growth pattern and the host reaction in the host infected with HO-S bacilli.

The findings in C57BL/6 and BALB/c mice were essentially the same with those obsereved in HO-R infected mice but the remarkable differences were shown in DDD and $\mathrm{C} 3 \mathrm{H}$ mice.

At 2 to 3 days, no significant differences in cellular reaction were found among 4 strains of mice. Many polymorphonuclears were observed and this infiltration as the inflammatory reaction to the inoclum was a little severer than that of HO-R infected mice. Most of the bacilli were ingested by macrophages and showed the same form and the same length of about 2 to $3 \mu$ as the inoculums.

At one week, the cellular reaction with many polymorphonuclears disappeared, leaving some polymorphonuclears in $\mathrm{BALB} / \mathrm{c}, \mathrm{DDD}$ and $\mathrm{C} 57 \mathrm{BL} / 6$ mice and a few in $\mathrm{C} 3 \mathrm{H}$ mice. Any morphological change of the bacilli was not observed and almost all the bacilli were in the macrophages.

At 3 weeks, a small benign type nodule was observed in C57BL/6 but not in the other strains. In $\mathrm{C} 57 \mathrm{BL} / 6$ mice, heavy lymphocytic infiltration occured, surrounding small number of murine leprosy cell and polymorphonuclears were also seen in small number. Most of the murine leprosy cells contained a few bacilli and some of them were bursting. The number of bacilli was already decreased significantly. In $\mathrm{C} 3 \mathrm{H}$ mice, murine leprosy cells which ingested many bacilli were diffusely scattered or accumulated in whole fields of the specimens without any cellular infiltration. The bacilli showed a little elongated form and were uniformly stained. Heavy cellular reaction seen in C57BL/6 was not observed in DDD mice, but slight infiltration with lymphocytes and polymorphonuclears was shown.

At 5 weeks, a small benign type nodule appeared in DDD mice and differences in the cellular reaction between $\mathrm{C} 3 \mathrm{H}$ and the other 3 strains were augmented. Heavy cellular reactions were developed in C57BL/6 (Fig. 7, 8), DDD and BALB/c. Macrophages cantained a small number of bacilli were surrounded by polymorphonuclears and lymphocytes. Bacilli in the murine lepprosy cells showed thinner form in these 3 strains of mice. Further increase of murine leprosy cells were recognized only in $\mathrm{C} 3 \mathrm{H}$ mice (Fig. 9) without any cellular reaction observed in the other strains.

At 7 to 8 weeks, it was difficult to make good preparations from central part of the infection site except $\mathrm{C} 3 \mathrm{H}$ mice, because much heavy infiltration developed than that of the other 3 strains at 5 weeks. In $\mathrm{C} 57 \mathrm{BL} / 6, \mathrm{BALB} / \mathrm{c}$ and DDD mice, there were a few bacilli and severe cellular reactions with lymphocytes and polymorphonuclears. At this stage, very remarkable change began to occur in $\mathrm{C} 3 \mathrm{H}$ mice (Fig. 10, 11). Murine leprosy cells were decreased distinctly and small masses of these cells were observed in restricted parts of the spacimen. Many lymphocytes infiltrated into these masses. These findings looked like those of C57BL/6 mice at 3 weeks. In murine leprosy cells of $\mathrm{C} 3 \mathrm{H}$ mice it was difficult to find out solid form bacilli, many bacilli showed elongated, beaded and segmented forms and there were many debris which were considered to be yielded from vanished bacilli.

At 10 weeks, in $\mathrm{C} 3 \mathrm{H}$ mice, cellular reaction developed gradually. Many lymphocytes and 
polymorphonuclears were observed and some of them accumulated around the small masses of murine leprosy cells. The bacilli decreased in number, furthermore, almost all the bacilli showed non-solid forms.

At 15 to 20 weeks, additional observation was done on C3H mice (Fig. 12). Many murine leprosy cells, which were heavily loaded with somewhat short and well stained bacilli, were observed and the cellular reaction almost disappeared. About 50 murine leprosy cells were accumulated to overlap each other. These features composed of round shaped murine leprosy cells were clearly margined and about $300 \mu$ in diamater. They were very characteristic and considered as the feature of bacillary multiplication.

\section{Discussion}

As stated in our previous reports $\left({ }^{10,11,12}\right)$ on the pathogenicity of HO-R and HO-S bacilli in mice, HO-R bacilli were found to be more virulent for mice than $\mathrm{H}-\mathrm{M}$ bacilli. And HO-S bacilli were generally so less virulent for mice than HO-R and H-M that HO-S bacilli did not produce any palpable leproma at the inoculation site in $\mathrm{C} 3 \mathrm{H}$ mice even in 40 weeks after the subcutaneous infection.

Differences of the cellular reaction in the subcutaneous lesion in the host infected with HO-R, HO-S and H-M were assumed to be due to their pathogenicity. From this point of view, in this experiment the observations were made by means of the spread subcutaneous tissue preparation technique to clear when the pathological differences begin to occur and how they developed at the inoculation site.

In $\mathrm{C} 3 \mathrm{H}$ mice infected with HO-R bacilli, there were no palpable lesions at the inoculation site in the first 10 weeks, but characteristic infiltration mainly composed of bacilli-loaded macrophages (murine leprosy cells) developed gradually. On the contrary, in C57BL/6 mice infected with HO-R bacilli, severe lymphocytic reaction with polymorphonuclears began to occur at the $3 \mathrm{rd}$ week and further multiplication of the bacilli was restricted. These differences in cellular reactions between $\mathrm{C} 3 \mathrm{H}$ and $\mathrm{C} 57 \mathrm{BL} / 6$ mice infected with HO-R were similar to those in our earlier experiments with $\mathrm{H}-\mathrm{M}$ bacilli infection $\left({ }^{(13}\right)$, so it was considered that the pathogenicity of HO-R bacilli for $\mathrm{C} 3 \mathrm{H}$ and $\mathrm{C} 57 \mathrm{BL} / 6$ mice was essentially the same with that of H-M bacilli. Closs and Haugen $\left({ }^{14}\right)$ observed a vigorous granulomatous reaction developed in $\mathrm{C57/BL}$ mice and arresting of further local spread of infection after subcutaneous inoculation with murine leprosy bacilli. Poulter and Lefford $\left({ }^{15}\right)$ reported that, in $\mathrm{B} 6 \mathrm{D} 2$ mice, delayed type hypersensitibity developed 4 weeks after subcutaneous infection with $M$. lepraemurium and concomitant reduction in number of the organisms was observed. Furthermore, we observed typically malignant murine leprosy disease in $\mathrm{C} 3 \mathrm{H}$ mice and $\mathrm{BALB} / \mathrm{c}-n u / n u$ mice $\left({ }^{9}\right)$. Considering these results, it is reasonable to regard that the histopathological changes shown in C57BL/6 and BALB/c mice are due to the cell-mediated immunity elicited and developed after infection with the bacilli, whereas this cell-mediated immunity developed poorly in $\mathrm{C} 3 \mathrm{H}$ mice. The findings on spread tissue preparations prepared from experimental mice indicated that the protective immunity to murine leprosy 
bacilli and regression of infection began to occur 3 weeks after the infection in resistant mice as regarded by Closs and Haugen $\left({ }^{16}\right)$.

The features observed in DDD mice were of interest. Although lymphocytic reaction was found from the $3 \mathrm{rd}$ to the 5 th week after infection with HO-R bacilli in DDD mice, one of the DDD mice showed the pathological changes at the 8 th week as observed in $\mathrm{C} 3 \mathrm{H}$ mice and accumulation of lymphocytes and polymorphonuclears around the murine leprosy cells disappeared in every specimen at 10 weeks. On the other side, it was found that DDD mice infected with H-M bacilli showed heavy cellular reaction with lymphocytes and polymorphonuclears from the $3 \mathrm{rd}$ week of infection and multiplication of the bacilli was restricted strongly as observed in $\mathrm{C} 57 \mathrm{BL} / 6 \mathrm{mice}\left({ }^{13}\right)$. However, it is obvious that these differences between the features obtained from $H-M$ infection and these from HO- $R$ infection are not due to the technical error, because HO-R infected male mice showed some variations of leproma type and most of lepromata were malignant $\left({ }^{7}\right)$. In this experiment it was indicated that the difference of susceptibility to HO-R and H-M bacilli in DDD mice began to clear at about 8 weeks of infection. The fidings in DDD mice infected with HO-R indicated that protective immunity of DDD mice to HO-R bacilli developed in some extent from the 3 rd to the 5 th week, but these host reactions decreased from the 8 th week. However, the mechanisms behind this phenomenon remains to be elucidated.

In $\mathrm{C} 3 \mathrm{H}$ mice infected with HO-S bacilli, bacilli-loaded macrophages were found and no host reactions were detected at the inoculation site as in the experiments with $\mathrm{H}-\mathrm{M}$ and HO-R bacilli untill 5 weeks after the infection. At 7 to 8 weeks, polymorphonuclear and lymphocytic infiltration was observed and the bacilli significantly decreased in number. As mentioned repeatedly $\left({ }^{13}\right)$ such host reaction was not seen at 7 to 8 weeks in $\mathrm{C} 3 \mathrm{H}$ mice infected wtih H-M bacilli and HO-R bacilli. But in 15 to 20 weeks gradual restoration of bacillary multiplication was shown and cellular reaction disappeared. Closs $\left({ }^{(7)}\right)$ and Lagrange( $\left.{ }^{18}\right)$ described that killed $M$. lepraemurium did not elicite delayed type hypersensitivity in mice and also in our studies by STP, naturally died bacilli did not show any pathological changes (to be published). Therefore, it is unreasonable to consider that killed bacilli in the inoculum caused the cellular reactions at 7 to 10 weeks. As the cellular reactions at 7 to 10 weeks in $\mathrm{C} 3 \mathrm{H}$ mice infected with HO-S bacilli were quite alike with those of $\mathrm{C} 57 \mathrm{BL} / 6$ mice infected with HO-R and H-M bacilli, it is reasonable to consider that protective immuno-responses were temporarily evoked in $\mathrm{C} 3 \mathrm{H}$ mice at 7 to 10 weeks after infection with HO-S bacilli and vanished after these stages of infection.

As reported before $\left({ }^{11,12}\right)$, development of mouse leprosy in $\mathrm{C} 3 \mathrm{H}$ mice with HO-S bacilli was extremely slow compared with that of HO-R and H-M infection. In the present study it was found that the lag of disease in $\mathrm{C} 3 \mathrm{H}$ mice is based not only on the poor in vivo growth of the bacilli but also on the host reaction.

In the present studies, the features of the cellular reactions and growth patterns of HO-R and HO-S bacilli in each mouse were well correlated with leproma type in long term observation. By using STP technique the prognosis of mouse leprosy can be predicted, with 
special reference to the host reaction against $M$. lepraemurium.

\section{Summary}

Cultivated murine leprosy bacilli from rough colonies (HO-R) and smooth colony variant (HO-S) were subcutaneously inoculated into mice of inbred strains (C3H, C57BL/6, BALB/c and DDD). Growth patterns of the bacilli of each strain and cellular reactions of host in subcutaneous tissue at the inoculation site were examined by means of the spread tissue preparation technique.

There were no remarkable differences in cellular reactions at the inoculation site among these inbred strains of mice infected with HO-R bacilli 2 days and 1 week after the infection. An acute inflammatory reaction with accumulation of many polymorphonuclears was observed at 2 days. At one week, it was disappeared and monocytes and macrophages were dominant. A vigorous granulomatous reaction consisted of polymorphonucleares and lymphocytes developed in $\mathrm{C} 57 \mathrm{BL} / 6, \mathrm{BALB} / \mathrm{c}$ and $\mathrm{DDD}$ mice at 3 weeks. In the course of the following weeks the cellular reaction was augmented in C57BL/6 and BALB/c mice and further local spread of the infection was arrested. On the other hand, in DDD mice the diminution of cellular reaction occured at 8 weeks and bacilli increased in number. In contrast, no signs of host reactions were observed in $\mathrm{C} 3 \mathrm{H}$ mice and many murine leprosy cells were observed at the inoculation site.

C57BL/6 and BALB/c mice infected with HO-S bacilli showed essentially the same host reaction as those observed in the experiment with HO-R bacilli. The diminution of cellular reaction observed in the DDD mice infected with HO-R bacilli could not be found in those infected with HO-S bacilli and the multiplication of the bacilli was not seen. In $\mathrm{C} 3 \mathrm{H}$ mice infected with HO-S bacilli no specific host reaction was found untill 5 weeks, but cellular reactions happened at 7 to 8 weeks which were never observed in $\mathrm{C} 3 \mathrm{H}$ mice infected with HO-R or H-M bacilli. The bacilli decreased in number from the 8 th to the 10 th week but bacillary multiplication was gradually recovered at 15 weeks. The multiplication of HO-S bacilli was very slow even in $\mathrm{C} 3 \mathrm{H}$ mice throughout the observation period.

In this study, we found that slower development of mouse leprosy with HO-S bacilli in $\mathrm{C} 3 \mathrm{H}$ mice is due to their poor ability to multiply in vivo and the inexplicable host reaction.

The mouse strain differences in response to cultivated $M$. lepraemurium were also discussed on the bases of cell-mediated immunity in the host.

\section{References}

1) Ogawa, T. and Motomura, K.: Studies on murine leprosy bacillus. 1. Attempt to cultivate in vitro the Hawaiian strain of Mycobacterium lepraemurium. Kitasato Arch. Exp. Med., 43, 21-36 (1970).

2) Koseki, Y., Anchi, T. and Okamoto, S.: Ogawa's bacillus: Slow growing mycobacteria isolated from mice previously infected with murine leprosy bacillus. I. In vitro cultivation and animal inoculation. La lepro, 41, 127-136 (1972).

3) Mori, T.: Cultivation of $M$. lepraemurium on the $1 \%$ Ogawa yolk medium and animal inoculation with cultivated $M$. lepraemurium. La lepro, 43, 226-233 (1976). 
4) Pattyn, S. R. and Portaels, F. : In vitro cultivation of Mycobacterium lepraemurium. Int. J. Lepr., 48, 7-14 (1980).

5) Ogawa, T.: Some observations on primary and secondary cultivations of M. lepraemurium. An abstract of presented paper at 49 th general meeting of Japanese leprosy assosiation. La lepro, 45, 101 (1976).

6) Matsuoka, M., Kabayashi, Y. and Kawaguchi, Y.: Scanning electron microscopic study of cultivated murine leprosy bacilli. An abstract of presented paper at 50 th general meeting of Japanese leprosy association. Jap. J. Lepr., 46, 194 (1977).

7) Okada, S., Nishimura, M., Ogawa, T. and Mori, T. : Electron microscopic study of colonies of Mycobacterium lepraemurium. Int. J. Lepr., 46, 364-371 (1978).

8) Kawaguchi, Y. : Classification of mouse leprosy. Jap. J. Exp. Med., 29, 651-663 (1959).

9) Kawaguchi, Y., Matsuoka, M., Kawatsu, K., Homma, J. Y. and Abe, C. : Susceptibility to murine leprosy bacilli of nude mice. Jap. J. Exp. Med., 46, 167-180 (1976).

10) Kawaguchi, Y., Matsuoka, M. and Kawatsu, K.: Pathogenicity of cultivated murine leprosy bacilli of Hawaiian-Ogawa strain in mice. 1. The pathogenicity of bacilli from rough colonies. Jap. J. Exp. Med., 48, 17-26 (1978).

11) Kawaguchi, Y., Matsuoka, M. and Kawatsu, K.: Pathogenicity of cultivated murine leprosy bacilli in mice. 2. The pathogenicity of bacilli from smooth colonies. Jap. J. Exp. Med., 48, 211-217 (1978).

12) Kawaguchi, Y., Matsuoka, M., Sushida, K. and Tanemura, M. : Pathogenicity of cultivated murine leprosy bacilli of Hawaiian-Ogawa strain in mice. 3. Transmission of bacilli recovered from subcutaneous leproma induced with smooth-colony variants. Jap. J. Exp. Med., 49, 27-32 (1979).

13) Kawaguchi, Y. and Matsuoka, M. : Observation of host reaction to murine leprosy bacilli in spread subcutaneous tissúe preparations of various strains of mice. Jap. J. Exp. Med., 47, 7179 (1977).

14) Closs, O. and Haugen, O. A. : Experimental murine leprosy. 3. Early local reaction to $M y c o-$ bacterium lepraemurium in $\mathrm{C} 3 \mathrm{H}$ and $\mathrm{C} 57 / \mathrm{BL}$ mice. Acta pathol. Microbiol. Scand. Sect. A., 83, 51-58 (1975).

15) Poulter, L. W. and Lefford, M. J. : Development of delayed-type hypersensitivity during $M y c o-$ bacterium lepraemurium infection in mice. Infec. Immun., 7, 439-446.

I6) Closs, O. and Haugen, O. A. : Experimental murine leprosy. 4. The gross appearance and microscopic features of the local infiltrate after subcutaneous inoculation of $\mathrm{C} 3 \mathrm{H}$ and $\mathrm{C} 57 / \mathrm{BL}$ mice with Mycobecterium lepraemurium. Acta pathol. Microbiol. Scand. Sect. A., 83, 59-68 (1975).

17) Closs, O.: Experimental murine leprosy. Induction of immunity and immunoparalysis to $M y c o-$ bacterium lepraemurium in C57/BL mice. Infect. Immun., 12, 706-713 (1975).

18) Lagrange, P. H. and Hurtrel, B.: Local immuno response to Macobacterium lepraemurium in in $\mathrm{C} 3 \mathrm{H}$ and $\mathrm{C} 57 \mathrm{BL} / 6$ mice. Clin. Exp. Immunol., 38, 461-474 (1979). 


\title{
培養鼠攋菌に対する宿主反応のマウス皮下 組織伸展標本による観察
}

\author{
松岡 正典川口陽一郎 \\ (国立多摩研究所)
}

培養鼠瀬菌の Rough 型菌とその変異株である Smooth 型菌を $\mathrm{C} 3 \mathrm{H}, \mathrm{C} 57 \mathrm{BL} / 6, \mathrm{BALB} / \mathrm{c}, \mathrm{DDD}$ 系の各マウス に皮下接種し, それぞれの菌の接種局所における增殖と 宿主反応差を伸展標本を用いて観察した。

Rough 型菌を接種されたマウスでは接種後 2 日目と 1 週目には系統間差は認められなかった。即ち2 日目に は非特異的異物反灾として多核白血球が多数認められ， 1 週目にはこの反态消失し, ほぼ単核球のみが観察さ れた。3週目に扔いて C57BL/6, BALB/c, DDD の各マ ウスでは多核白血球，リンパ球からなる宿主細胞反応が 出現し， C57BL/6, BALB/c マウスではこれらの反応は 以後, 增強され菌の增殖は抑制された。これらの反忍は マウス継代株による伸展標本像と同じであり宿主におけ る免疫反念の発達を反影したむのであると推察された。 DDD マウスではマウス継代株接種後観察された良性型 結節像は 8 週頃より消失し菌は再び增殖した。DDD マ ウスはマウス継代株に対しては強い抵抗を示すのに対 し，Rough 型菌はこのマウスに対し強い病原性を示す といら長期観察実験の結果とよく相関した像が得られ
た。C3H マウスは典型的悪性型結節像を呈し，他の采 統のマウスで見られた特異的細胞反応山観察されずマウ ス継代株に上る伸展標本像と同様の像を示した。

Smooth 型菌を接種された C57BL/6 マウスおよび $\mathrm{BALB} / \mathrm{c}$ マウスの宿主反応と菌増殖像は Rough 型菌に おける経時的変化とほぼ同じであった。一方 DDD マウ スでは Rough 型菌接種時観察された宿主抵抗の減退像 はなく C57BL/6 マウス, BALB/c マウスとほぽ同じ伸 展標本像老した，C3H マウスは 5 週目までマウス継 代株，Rough 型菌接種による伸展標本像と同じ変化を 示したものの7週から8週に加けて宿主細胞反応が出現 し，更に 8 週から 10 週目に扔いては菌数は著るしく減 少した。15週日以後菌の增殖は徐々に回復したものの その堌殖像は特街的な像であった。Smooth 型菌の病原 性は他の株に比し著るしく低下していることが示唆され $\neq 0$

それぞれのマウスにおける宿主反応像と宿主の免疫反 㐫の発達との相関についても言及した。 


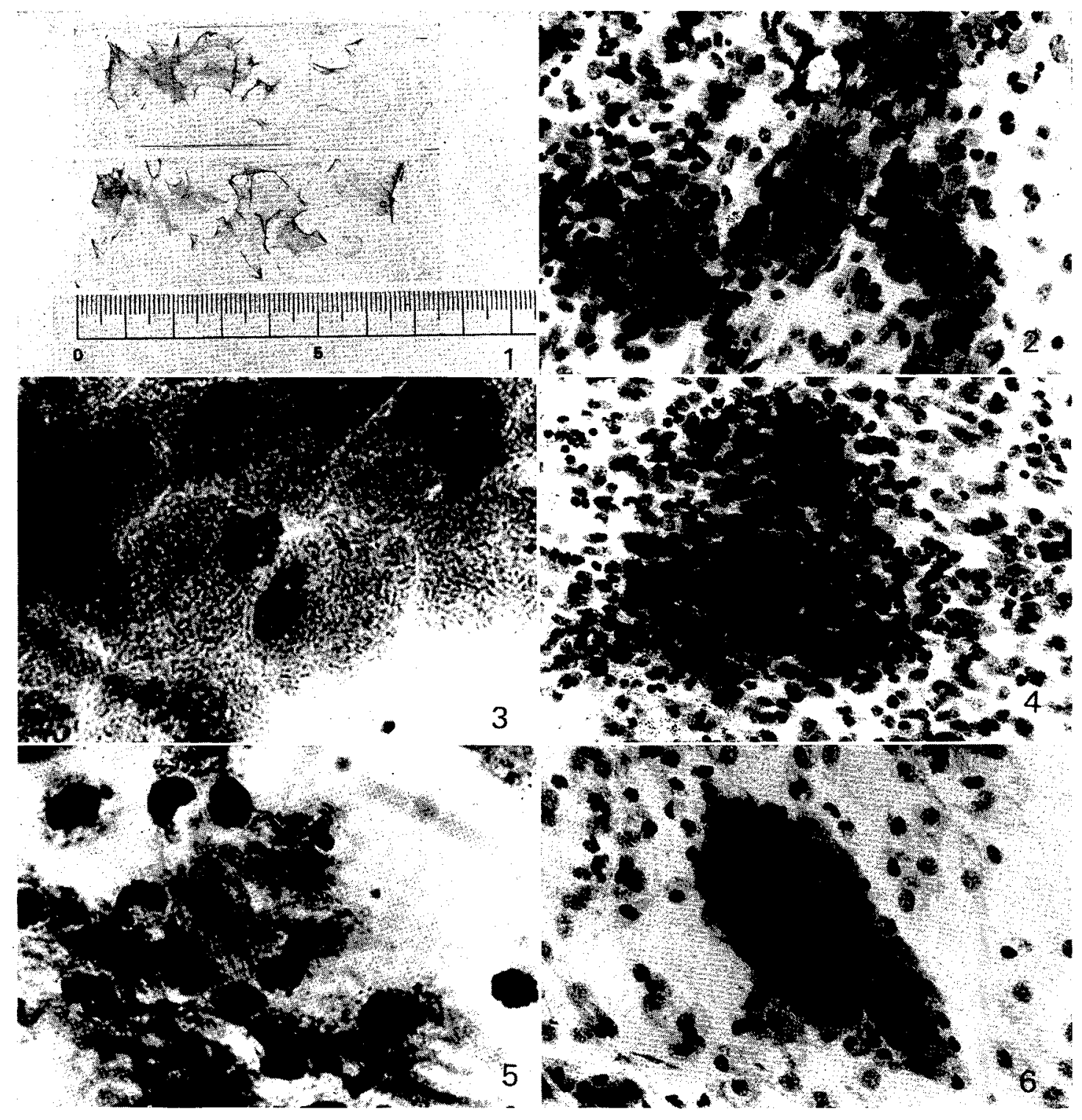

Fig. 1 The gross appearance of Ziehl-Neelsen stained STP.

Fig. $2 \mathrm{C} 3 \mathrm{H}$ mouse, 5 weeks after infection with $\mathrm{HO}-\mathrm{R}$ bacilli. $\times 200$.

Fig. $3 \mathrm{C} 3 \mathrm{H}$ mouse, 5 weeks after infection with $\mathrm{HO}-\mathrm{R}$ bacilli. $\times 1,000$.

Fig. 4 C57BL/6 mouse, 5 weeks after infection with HO-R bacilli. $\times 200$.

Fig. $5 \mathrm{C} 57 \mathrm{BL} / 6$ mouse, 5 weeks after infection with $\mathrm{HO}-\mathrm{R}$ bacilli. $\times 1,000$.

Fig. 6 DDD mouse, 10 weeks after infection with HO-R bacilli. $\times 200$. 


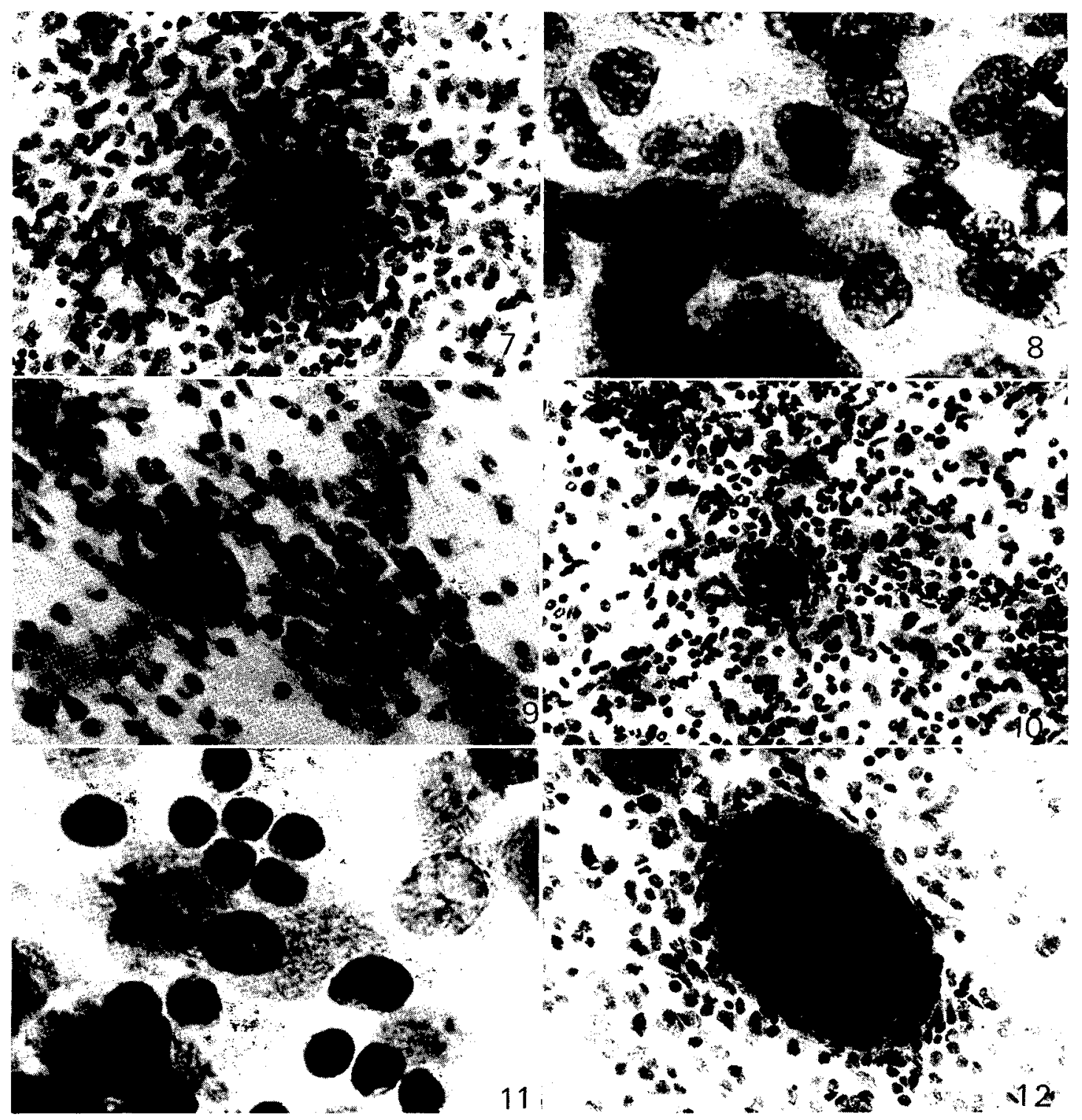

Fig. 7 C57BL/ 6 mouse, 5 weeks after infection with HO-S bacilli. $\times 200$.

Fig. $8 \mathrm{C} 57 \mathrm{BL} / 6$ mouse, 5 weeks after infection with $\mathrm{HO}-\mathrm{S}$ bacilli. $\times 1,000$.

Fig. $9 \mathrm{C} 3 \mathrm{H}$ mouse, 5 weeks after infection with $\mathrm{HO}-\mathrm{S}$ bacilli. $\times 200$.

Fig. $10 \mathrm{C} 3 \mathrm{H}$ mouse, 7 weeks after infection with $\mathrm{HO}-\mathrm{S}$ bacilli. $\times 200$.

Fig. $11 \mathrm{C} 3 \mathrm{H}$ mouse, 7 weeks after infection with $\mathrm{HO}-\mathrm{S}$ bacilli. $\times 1,000$.

Fig. $12 \mathrm{C} 3 \mathrm{H}$ mouse, 20 weeks after infection with HO-S bacilli. $\times 200$. 